\title{
WOMEN WORKFORCE LOOKING THROUGH THE GLASS CEILING
}

\author{
Reyhan Sarıçiçek ${ }^{1 *}$, Filiz Çopuroğlư ${ }^{2}$, Mehmet Aytekin ${ }^{3}$ \\ ${ }^{1}$ Lecturer, Gaziantep University, TURKEY, reyhans@gantep.edu.tr \\ ${ }^{2}$ Lecturer, Gaziantep University, TURKEY, filizcokay@gantep.edu.tr \\ ${ }^{3}$ Asst. Prof., Gaziantep University, TURKEY, aytekin@gantep.edu.tr \\ ${ }^{*}$ Corresponding Author
}

\begin{abstract}
Women have begun to take part in business life intensively in the last century. However, despite the rapid rise in the number of women in business world, the proportion of women among senior managers and leaders has been very low. Research on the subject demonstrates that women face difficulties called 'Glass Ceiling', which cannot be seen apparently and at the same time which is hard to overcome in order to reach the senior executive positions. Glass ceiling refers to the difficulties that take place between women and the top management which do not allow them to move along their career regardless of their success and skills. There have been many theories about why women are underrepresented in senior management positions. If gathered under three headings, these are: Bias-centred, person-centred, and structural-centred theories. Bias-centred theories consider that the fundamental causes of inequalities are discrimination, stereotyping and prejudice by the greater part of the society or dominant group. Person-centred theories accept that differences in men's and women's personal characteristics and behaviour cause women to be unsuccessful at management positions. Structural-centred theories suppose that the main causes of inequality are the structural policies and customs of a social system, thus social structure dominated by men raise the discrimination against women.
\end{abstract}

In this paper 'Glass Ceiling Syndrome' has been researched, the related literature on the subject has been investigated and the results were tried to be tested by a field survey. Within the scope of the study, a questionnaire was developed to determine the perception and attitudes of women who are working in a research hospital in Izmir on "Glass Ceiling Syndrome". The glass ceiling was analysed at nine dimensions in the questionnaire; these are: barriers stemming from top management, negative prejudices against women, family life, sex discrimination, women's rise in their career, organizational culture and politics, informal communication networks, mentoring and occupational discrimination.

Research has shown that women are uncomfortable with prejudices about themselves and now they are ready for senior management positions. Women have been also more conscious day by day and they have been trying to break the glass ceiling which is like a barrier on their career. Eventually it can be said that the increase in educational and cultural level of the society will be the main factor on breaking the glass ceiling.

Keywords: Glass Ceiling Syndrome, Female Managers, Gender in Work Life, Gender Discrimination 


\section{THE CONCEPT OF GLASS CEILING}

The concept of glass ceiling was widely first used in 1986 on Wall Street Journal, in the corner of "Corporate Women" by Hymowitz and Schellhardt (Güldal, 2006:61). They point detailed imperceptible obstacles faced by female managers, stymied by "corporate tradition and prejudice" rather than apparent discrimination. The glass ceiling is a concept that is interested in the barriers faced by women who attempt or desire to attain senior positions in companies, government, education and non-profit organizations (Lockwood, 2004:1). Manager positions seem like a state that women can reach but they cannot break the glass ceiling. The invisible limit that prevents qualified women from reaching high positions in organizations is named as "glass ceiling" (Hopman and Lord, 2009:3). In this respect, "glass ceiling" represents every kind of prevention and injustice that women face when reaching high positions in firms (Mescon, Bovee and Thill, 2001).

\section{THEORIES THAT EXPLAIN GLASS CEILING}

Statements of "glass ceiling" can be defined under three headings; bias centred, person centred and structural centred theories. (Hopman and Lord, 2009:5).

\subsection{Bias Centred Theories}

Bias centred theories presume that society or a dominant group that form a stereotype or prejudice is the main reason of inequality. Discrimination is treating a person differently because of his/her sex or race (Hopman and Lord, 2009:6). Sexual discrimination emerges when employees evaluated not based on their performances or qualities but based on their sexes (Seçer, 2009:42). Women percept sexual discrimination as a result of certain outputs, low power and confidence, low perceived prestige in business life, intense conflicts in the workplace, increasing depression and anxiety levels could be instances of such certain outputs (Onay, 2009:285).

Discrimination shows itself in very different forms and one of them is "Queen Bee Syndrome". Queen bee syndrome is a type of discrimination in which a professional woman who is successful in social life (let us say a woman who is very powerful in business) who has succeeded without getting help from women and has taken initiative thus thinks carelessly that other women can make it as she did. Queen bee may use her power to discourage other women and stop their progress. Queen bee syndrome is perceived as a problem because although women in high positions could aid other women's advancement they are the least willing people to do so (Hopman and Lord, 2009:6). According to women managers, who have queen bee syndrome, unsuccessful women should blame themselves and act against sexist applications and strive individually to eliminate such applications of discrimination (Sezen, 2008:26).

Throughout time, men and women worked together but the outcome of their work was not evaluated equally and women were stated as secondary (Çelikten, 2004:92). The secondary statue of women in her business life is no different in her family life. The condition of a working woman is not considered as an opportunity for her to earn her freedom and life but as an extra income for home budget (Demiray, 2007:349).

The description of Hymowitz and Schellhardt about a stereotypical group is a strong generalisation that all the members of the group carry the 'so-called' qualities of the specific group (Hopman and Lord, 2009:7). Stereotypes are obstacles that prevent women from becoming more active (Ruderman and Ohlott, 2005: 129-130). One of those stereotypes is the belief that women will not be coming back for work after having children. However researches show that women return to job after having children. Contrary to this fact, investors do not strive for women with children to progress because they believe the general opinion that women do not return after having children (Hopman and Lord, 2009:7). Also, while employing questions such as "Do you think to get married?" or "When do you plan to have children?" are asked to women which are never asked to men (www.psikonet.com). The family and childbirth responsibilities affect negatively a woman's career to become a manager.

Another stereotype is "token" (Symbol) woman obstacle. This is the statement of some men that firms employ women on that specific positions in order to look like they are not an organisation where a sexual discrimination is present (Hopman and Lord, 2009:8). When firms appoint women in board of managers or in ineffective committees, it is not related to the skills or potential additives of women; but it is a way of giving away tokens in order to maintain their images as non-sexist (Öğüt, 2006:63).

\subsection{Person Centred Theories}

Person centred theories defend the idea that the difference between male and female characteristics and attitudes cause a disadvantage for women because their nature is not suitable for management (Hopman and Lord, 2009:8). 
In Japan there is a saying as "Otoko no shakai" meaning "world of men". Certainly, almost everywhere business world is a world of men. Rules are set by men according to men. For these reasons, women who try to take part in this world undertake a masculine role from clothing to attitude (Yelkikalan, 2006:46).

The aggressive nature of individual structures makes it easy to risk. There is an intercultural quality that is universal, and it is that men are more aggressive than women. Risking is a skill that men claim to own. In addition, these claims are multiplied with manly games and particularly with team sports (Deemer and Frederics, 2006:228). They learn the principal "Sometimes you win and sometimes you lose" and they grow up to become a man then carry this particular attitude to business life. As opposed to this, most of women who are in management role, as a natural fact, are shy to risk. When a woman reaches a higher position in her career in business life she becomes a stranger in that position. While her male colleagues risk all the time, she is in a process of getting accustomed to risking. For this reason, she chooses to operate within all the rules and guarantee herself. As a result, she cannot take risky actions which would make her advancement and her progress inevitably slows down (Deemer and Frederics, 2006:229).

\subsection{Structural Centred Theories}

Structural centred theories accept the traditional customs and rules of a community system as the origin point of inequalities. A community system which is patriarchal multiplies discrimination against women (Hopman and Lord, 2009:9). Women, in most countries of the world, are weak in reaching the basic functions that human life requires. Social and political inequalities prevent women from reaching these humane and natural basics that they should have naturally as a person (Harcar et al.,2008:68).

One of the structural theories is known as old boys network which is an informal data network in which women are traditionally excluded. These only-for-men networks make men feel safer for they are among only themselves as men. This way, men have chances to improve their relationships with colleagues, managers and customers which give men the opportunity to be successful in their careers. Women are excluded from such network, these networks are considered as a disadvantage for women (Hopman and Lord, 2009:9). Still, at many firms this kind of networks are present and researches show that women are excluded from these networks at high rate (Karaca, 2007:63).

Researchers showed that the roles of private and business lives result in contradicting demands and women who live in both fear to fail in both (Ruderman and Ohlott, 2005, 151). Man who progresses in his career is congratulated; however when a woman is successful, her adequacy about family responsibilities is questioned (Yoğun Ercen, 2008:10).

In society the roles given to women suit them with jobs related to housework, and the roles given to men suit them being successful in business life and reaching high statue positions (Yoğun Erçen, 2008:17). While a socializing man does it for business purposes a woman is expected to socialize with family members. When a woman's job is obstructive for housework, the situation may result in family issues. Women put on a considerable amount of effort to undertake responsibilities of business and family lives (Anafarta, Sarvan and Yapıcı, 2008:116).

\section{RESEARCH METHOD}

The participants of this research are women workers of Ministry of Health Tepecik Training and Research Hospital. For this research, a number of 205 survey papers were distributed, 6 of them did not return, another 6 of them disqualified due to application and filling errors and as a result a number of 193 survey papers were included in the analysis. In this work, which aimed to research opinions of women hospital workers about "Glass Ceiling Syndrome", a questionnaire was developed to determine the perception and attitude of them. In creating the questionnaire the works of Karaca (2007) and Sezen (2008) were benefited from; but the question forms of these researches were not used as the same, mentioned some changes and supplementations were made. The data acquired in the end of research were analysed using computer software SPSS 16.00 for Windows. The Likert type scale was used in the research questions and they were graded as follows:

Table 1. Points of Options and Numeric Limits

\begin{tabular}{|c|c|c|}
\hline Points & Options & Numeric Limits \\
\hline 0 & Strongly Disagree & $0,00-0,79$ \\
\hline 1 & Disagree & $0,80-1,59$ \\
\hline 2 & Neither Agree Nor Disagree & $1,60-2,39$ \\
\hline 3 & Agree & $2,40-3,19$ \\
\hline 4 & Strongly Agree & $3,20-4,00$ \\
\hline
\end{tabular}




\subsection{Data and Findings}

When examining according to age range of participants, more than half of them are between 26-35 with $52.3 \%$. It is followed by $36-45$ age range with $18.7 \%$. While there are people who are 25 or younger with $17.6 \%$, people range between $46-55$ with $8.8 \%$ and people who are 56 or more are with $2.6 \%$.

When examining according to marital status of participants, married are with $53.9 \%$. Singles are with $37.8 \%$ and divorced are with $8.3 \%$.

When examining according to education levels of participants, high school graduates are with $22.3 \%$, university graduates are with $29 \%$ master and doctorate graduates are with $20.7 \%$.

When examining according to duty areas of participants, the most employees work in medical units with $53.9 \%$. Management units follow them with $37.8 \%$. Upon looking at the range of jobs there are nurses at most with $30.1 \%$. It is followed by secretaries with $22.3 \%$. Doctors with $17.6 \%$ and managers with $16.1 \%$, and people on other duties are with $13.5 \%$.

Table 2. Obstacles Origin from Upper Management

\begin{tabular}{|l|c|c|c|}
\hline Obstacles Origin From Upper Management & Average & $\begin{array}{c}\text { Standard } \\
\text { Deviation }\end{array}$ & $\begin{array}{c}\text { Perception Level } \\
\text { Related to Average } \\
\text { Points }\end{array}$ \\
\hline $\begin{array}{l}\text { Women should work harder to get to } \\
\text { management positions }\end{array}$ & 1,74 & 1,38 & $\begin{array}{c}\text { Neither Agree Nor } \\
\text { Disagree }\end{array}$ \\
\hline $\begin{array}{l}\text { Women are given lower positions in respect of } \\
\text { their skills }\end{array}$ & 2,15 & 1,12 & $\begin{array}{c}\text { Neither Agree Nor } \\
\text { Disagree }\end{array}$ \\
\hline My superiors aid my career progress & 1,95 & 1,12 & $\begin{array}{c}\text { Neither Agree Nor } \\
\text { Disagree }\end{array}$ \\
\hline 1. Dimension & 1,95 & 0,74 & $\begin{array}{c}\text { Neither Agree Nor } \\
\text { Disagree }\end{array}$ \\
\hline
\end{tabular}

In Table 2, the responses women gave to the questions on Obstacles Origining from Upper Management are seen. In this part it is aimed to determine the obstacles from upper management for women in pursue of management. The opinions about the statements "Women should work harder to get to management positions", "Women are given lower positions in respect of their skills" and "My superiors aid my career progress" resulted in the same conclusion in different platforms. As a result, women cannot decide whether they got help from upper manager for their career progress or not.

Table 3. Negative Bias about Women

\begin{tabular}{|l|c|c|c|}
\hline Negative Bias About Women & Average & $\begin{array}{c}\text { Standard } \\
\text { Deviation }\end{array}$ & $\begin{array}{c}\text { Perception Level } \\
\text { Related To Average } \\
\text { Points }\end{array}$ \\
\hline $\begin{array}{l}\text { Women struggle in decision to move to high level } \\
\text { management }\end{array}$ & 1,31 & 1,07 & Disagree \\
\hline Children prevent women from work & 1,76 & 1,21 & $\begin{array}{c}\text { Neither Agree Nor } \\
\text { Disagree }\end{array}$ \\
\hline Women can't do high level management & 0,68 & 0,95 & Strongly Disagree \\
\hline Women managers can't decide fast and logical & 0,91 & 1,05 & Disagree \\
\hline $\begin{array}{l}\text { Women can't succeed at management because } \\
\text { they are more sentimental than men }\end{array}$ & 0,98 & 1,15 & Disagree \\
\hline 2. Dimension & 1,13 & 0,58 & Disagree \\
\hline
\end{tabular}

In Table 3, the responses women gave to the questions on prejudices about their sex are seen. Women do not agree with the prejudices about them.

The highest denial is to "Women can't do high level management" statement with a rate of 0.68 . This can be perceived as an answer to react against prejudices about them. While women who participate in this research do not agree with statements such as "Women struggle in decision to move to high level management", "Women managers can't decide fast and logical" and "Women can't succeed at management because they are more sentimental than men", they cannot decide about the statement "Children prevent women from work". 
Table 4. Family Life

\begin{tabular}{|l|c|c|c|}
\hline Family Life & Average & $\begin{array}{c}\text { Standard } \\
\text { Deviation }\end{array}$ & $\begin{array}{c}\text { Perception Level } \\
\text { Related To Average } \\
\text { Points }\end{array}$ \\
\hline Women undertake too much family responsibilities & 2,94 & 1,10 & Agree \\
\hline I struggle to balance my business and family lives & 1,45 & 1,12 & Disagree \\
\hline I feel guilty for not having enough time for my family & 1,76 & 1,16 & $\begin{array}{c}\text { Neither Agree Nor } \\
\text { Disagree }\end{array}$ \\
\hline $\begin{array}{l}\text { I have to make family life sacrifices for my progress } \\
\text { at work }\end{array}$ & 2,10 & 1,12 & $\begin{array}{c}\text { Neither Agree Nor } \\
\text { Disagree }\end{array}$ \\
\hline $\begin{array}{l}\text { I would accept high position management even } \\
\text { though I think it will affect my family life in a bad } \\
\text { way }\end{array}$ & 2,23 & 2,39 & $\begin{array}{c}\text { Neither Agree Nor } \\
\text { Disagree }\end{array}$ \\
\hline 3. Dimension & 2,09 & 0,83 & $\begin{array}{c}\text { Neither Agree Nor } \\
\text { Disagree }\end{array}$ \\
\hline
\end{tabular}

Women participants agree to the statement "Women undertake too much family responsibilities" with an average of 2.94. This shows that women think the responsibilities they undertake is over the limit it should normally be. Women do not agree with the statement "I struggle to balance my business and family lives". This result shows us that women get used to their business life and they adopt it. And they replied to the statements "I feel guilty for not having enough time for my family", "I have to make family life sacrifices for my progress at work", "I would accept high position management even though I think it will affect my family life in a bad way" as Neither Agree Nor Disagree. When evaluated the dimension of family life, it is seen that women cannot decide whether they agree with the statements or not.

Table 5. Sexual Discrimination

\begin{tabular}{|l|c|c|c|}
\hline Sexual Discrimination & Average & $\begin{array}{c}\text { Standard } \\
\text { Deviation }\end{array}$ & $\begin{array}{c}\text { Perception Level } \\
\text { Related To Average } \\
\text { Points }\end{array}$ \\
\hline Women are given more opportunities of promotion & 1,45 & 1,03 & Disagree \\
\hline Men are given more opportunities of promotion & 2,25 & 1,19 & $\begin{array}{c}\text { Neither Agree Nor } \\
\text { Disagree }\end{array}$ \\
\hline $\begin{array}{l}\text { Women are given more opportunities of promotion } \\
\text { in management }\end{array}$ & 1,63 & 1,97 & $\begin{array}{c}\text { Neither Agree Nor } \\
\text { Disagree }\end{array}$ \\
\hline Women take insufficient account from their inferiors & 1,41 & 1,04 & Disagree \\
\hline $\begin{array}{l}\text { Women take insufficient account from their } \\
\text { superiors }\end{array}$ & 1,37 & 1,03 & Disagree \\
\hline $\begin{array}{l}\text { Women accepted that there are obstacles in career } \\
\text { for their sex }\end{array}$ & 1,46 & 1,15 & Disagree \\
\hline $\begin{array}{l}\text { Sex is a decisive and affective factor in respect of } \\
\text { manager requirements }\end{array}$ & 1,70 & 1,24 & $\begin{array}{c}\text { Neither Agree Nor } \\
\text { Disagree }\end{array}$ \\
\hline 4. Dimension & 1,61 & 0,64 & $\begin{array}{c}\text { Neither Agree Nor } \\
\text { Disagree }\end{array}$ \\
\hline
\end{tabular}

The average statement about sexual discrimination is as Neither Agree Nor Disagree. Participating women disagree with the statements "Women are given more opportunities of promotion", "Women take insufficient account from their inferiors", "Women take insufficient account from their superiors" and "Women accepted that there are obstacles in career for their sex". And they replied to the statements "Men are given more opportunities of promotion", "Women are given more opportunities of promotion in management" and "Sex is a decisive and affective factor in respect of manager requirements" as Neither Agree Nor Disagree.

Table 6. Factors that Made Women Climb Up Career Steps

\begin{tabular}{|l|c|c|c|}
\hline $\begin{array}{l}\text { Factors That Made Women Climb Up Career } \\
\text { Steps }\end{array}$ & Average & $\begin{array}{c}\text { Standard } \\
\text { Deviation }\end{array}$ & $\begin{array}{c}\text { Perception Level } \\
\text { Related To Average } \\
\text { Points }\end{array}$ \\
\hline $\begin{array}{l}\text { My education level was an important factor for me } \\
\text { to reach this position }\end{array}$ & 2,71 & 1,15 & Agree \\
\hline The information I gained from my superiors played & 2,52 & 1,04 & Agree \\
\hline
\end{tabular}


IJASOS- International E-Journal of Advances in Social Sciences, Vol. III, Issue 7, April 2017

\begin{tabular}{|l|c|c|c|}
\hline an important part in my promotion & & & Agree \\
\hline $\begin{array}{l}\text { The more work I did compared to my colleagues } \\
\text { earned me this position }\end{array}$ & 2,55 & 1,08 & Agree \\
\hline $\begin{array}{l}\text { The more performance I showed compared to my } \\
\text { colleagues played an important part in acquiring } \\
\text { this position }\end{array}$ & 2,58 & 1,07 & Agree \\
\hline 5. Dimension & 2,58 & 0,82 & \\
\hline
\end{tabular}

Participants replied to all statements about Factors that made women climb up career steps as Agree. With a rate 2.71 women consider their education is the most effective factor for their progress in career steps. With 2.58 the statement "The more performance I showed compared to my colleagues played an important part in acquiring this position" and with 2.55 "The more work I did compared to my colleagues earned me this position" and with 2.52 "The information I gained from my superiors played an important part in my promotion" are other agreed responses.

Table 7. Institutional Culture and Policies

\begin{tabular}{|l|c|c|c|}
\hline Institutional Culture And Policies & Average & $\begin{array}{c}\text { Standard } \\
\text { Deviation }\end{array}$ & $\begin{array}{c}\text { Perception Level } \\
\text { Related To Average } \\
\text { Points }\end{array}$ \\
\hline $\begin{array}{l}\text { Management role is given to men more often than } \\
\text { women }\end{array}$ & 2,26 & 1,27 & $\begin{array}{c}\text { Neither Agree Nor } \\
\text { Disagree }\end{array}$ \\
\hline $\begin{array}{l}\text { Women are not given enough opportunities on job } \\
\text { training }\end{array}$ & 2,20 & 1,39 & $\begin{array}{c}\text { Neither Agree Nor } \\
\text { Disagree }\end{array}$ \\
\hline At times of crisis women are first to be discharged & 2,10 & 1,09 & $\begin{array}{c}\text { Neither Agree Nor } \\
\text { Disagree }\end{array}$ \\
\hline $\begin{array}{l}\text { Women are exposed to discrimination on salary, } \\
\text { premium and statue. }\end{array}$ & 1,99 & 1,13 & $\begin{array}{c}\text { Neither Agree Nor } \\
\text { Disagree }\end{array}$ \\
\hline $\begin{array}{l}\text { Business life is governed according to male rules in } \\
\text { institutions }\end{array}$ & 1,93 & 1,75 & $\begin{array}{c}\text { Neither Agree Nor } \\
\text { Disagree }\end{array}$ \\
\hline 6. Dimension & 2,06 & 0,76 & $\begin{array}{c}\text { Neither Agree Nor } \\
\text { Disagree }\end{array}$ \\
\hline
\end{tabular}

In Table 7, the responses women gave to the questions on institutional culture are seen. All the statements in this dimension are replied to as 'Neither Agree Nor Disagree. The statement "Management role is given to men more often than women" is with an average of 2.26 and the statement "Women are not given enough opportunities on job training" is with 2.20 .

Table 8. Informal Communication Networks

\begin{tabular}{|l|c|c|c|}
\hline Informal Communication Networks & Average & $\begin{array}{c}\text { Standard } \\
\text { Deviation }\end{array}$ & $\begin{array}{c}\text { Perception Level related } \\
\text { to Average Points }\end{array}$ \\
\hline $\begin{array}{l}\text { Women can easily communicate with their male } \\
\text { colleagues and superiors }\end{array}$ & 2,76 & 1,03 & Agree \\
\hline $\begin{array}{l}\text { Men usually tend to act in favour of their male } \\
\text { colleagues because of their unofficial off-work } \\
\text { relationships with them }\end{array}$ & 2,07 & 1,08 & $\begin{array}{c}\text { Neither Agree Nor } \\
\text { Disagree }\end{array}$ \\
\hline $\begin{array}{l}\text { Women struggle to join male dominant } \\
\text { communication networks }\end{array}$ & 1,90 & 1,07 & $\begin{array}{c}\text { Neither Agree Nor } \\
\text { Disagree }\end{array}$ \\
\hline 7. Dimension & 2,24 & 0,74 & $\begin{array}{c}\text { Neither Agree Nor } \\
\text { Disagree }\end{array}$ \\
\hline
\end{tabular}

The statements about informal communication networks show that, participants agreed with the statement "Women can easily communicate with their male colleagues and superiors" with 2.76 . They replied to the statements "Men usually tend to act in favour of their male colleagues because of their unofficial off-work relationships with them" and "Women struggle to join male dominant communication networks" as neither agree nor disagree. 
IJASOS- International E-Journal of Advances in Social Sciences, Vol. III, Issue 7, April 2017

Table 9. Discrimination at Work

\begin{tabular}{|l|c|c|c|}
\hline Discrimination at Work & Average & $\begin{array}{c}\text { Standard } \\
\text { Deviation }\end{array}$ & $\begin{array}{c}\text { Perception Level } \\
\text { Related to Average } \\
\text { Points }\end{array}$ \\
\hline $\begin{array}{l}\text { Families guide their daughters to jobs that they } \\
\text { think are much more suitable for women }\end{array}$ & 2,33 & 1,24 & $\begin{array}{c}\text { Neither Agree Nor } \\
\text { Disagree }\end{array}$ \\
\hline $\begin{array}{l}\text { Decentralization differs according to sexes in } \\
\text { institution }\end{array}$ & 1,94 & 1,18 & $\begin{array}{c}\text { Neither Agree Nor } \\
\text { Disagree }\end{array}$ \\
\hline 8. Dimension & 2,13 & 0,99 & $\begin{array}{c}\text { Neither Agree Nor } \\
\text { Disagree }\end{array}$ \\
\hline
\end{tabular}

About discrimination at work, the statements "Families guide their daughters to jobs that they think are much more suitable for women" and "Decentralization differs according to sexes in institution" were replied as Neither Agree Nor Disagree.

\subsection{Results of the Research}

In this research, the subject of glass ceiling was analysed under eight different dimensions. These are "Obstacles Origining from Upper Management", "Negative Bias About Women", "Family Life, "Sexual Discrimination", Factors that Made Women Climb Up Career Steps", Institutional Culture and Policies", Informal Communication Networks" and "Discrimination at Work".

To the first dimension of research is "Obstacles Origining from Upper Management" the average reply of the participants to the related statements were as Neither Agree Nor Disagree. Although the replies of participants vary regarding to the second dimension of the research which is "Negative bias about women", women certainly disagree with the statement "Women can't do high level management". For the reason that all the participants clearly rejected this statement, it could be concluded that women feel discomfort about negative bias about them and feel ready to take part in high level management. In this dimension the only statement that women feel timid about is "Children prevent women from work". The reason for a changing in the belief that having children is an obstacle in business life is could be because of changing social roles, flexible work hours of firms for women with children and kindergarten facilities etc. In the third dimension, which is about 'Family Life' the average reply of the participants to the statements about family life is observed as Neither Agree Nor Disagree. The only statement that the participants rejected in this dimension is "I struggle to balance my business and family lives". Their disagreement to this statement could be a sign that they evaluate themselves as successful in balancing their lives. It could be said that the rise in number of working women is helpful for men and women in society to get used to the role of working mother and wife and with their environment getting accustomed to it, the situation resulted in an easing effect for women to balance their business and family lives. To the fourth dimension which is about 'Sexual Discrimination' the average reply of the participants is as Neither Agree Nor Disagree. While women underlined that they disagree with the statements implying that they are given more opportunities for promotion, they replied the statement "Men are given more opportunities in promotion" as 'Neither Agree Nor Disagree. This could be showing the presence of an issue that even women do not want to admit to themselves. The fifth dimension under which the subject 'Factors that Made Women Climb Up Career Steps' is taken into account, it is clearly stated that the most important factor for participants to advance in their career is job trainings they attended to. Other factors for women to advance in their careers are lined by participants as the more work they perform than their colleagues at work, the more work hours compared to their colleagues and the information and experience they gathered from their superiors. Statements about sixth dimension institutional culture general attitude of participants are expressed as Neither Agree Nor Disagree. This could be a sign that no positive or negative discrimination takes place towards working women in institution. On seventh dimension informal communication networks were taken into account. The participants expressed that they agree with the statement "Women can easily communicate with their male colleagues and superiors" and they showed that they are aware of their power in communication. On this dimension the general attitude towards other statements are expressed as Neither Agree Nor Disagree. To eighth and last dimension which is discrimination at work, participants shared their opinions as Neither Agree Nor Disagree. Although at past, jobs were grouped as male and female works the statement of participants Neither Agree Nor Disagree could be considered as a sign that the taboos on discrimination at work are slowly being shattered.

It is a common belief that glass ceiling is still present. On high management levels women are still not sufficiently represented (Hopman and Lord, 2009:11). Ruderman and Ohlott stated that there is an incredible rise in number of women managers however this situation did not mean that discrimination is over with the rise in number and it meant only that discrimination is less certain (Ruderman and Ohlott, 2005:22). 
Researches do not accept glass ceiling as a notion of past and they highlight that there are important issues to be concentrated on for women to progress in their careers (Hopman and Lord, 2009:11).

* This study was derived from master's thesis written at The University of Dokuz Eylül Institute of Social Sciences Department of Business Administration.

** This study was a submission on INTCESS 2017- 4th INTERNATIONAL CONFERENCE ON EDUCATION AND SOCIAL SCIENCES.

\section{REFERENCE LIST}

Anafarta, N., Sarvan F. and Yapıcı N. (2008). Glass Ceiling Perception of Women Managers at Boarding Firms: A Research in Antalya. The University of Akdeniz Faculty of Administrative Sciences Magazine, (15) 111-137.

Barutçugil, İ. (2002). Woman Manager in Business Life. Career Publish, İstanbul.

Beck, A. J. (2003). Through The Looking-Glass Ceiling: The Advancement of Women Administrators and Women Facility in an Institution of Higher Education. (Published Doctorate's Thesis), The University of Texas, Austin.

Çelikten, M. (2004). Women in the Seat of Principal Kayseri Example. The University of Erciyes the Faculty of Social Sciences Magazine, (17) 91-118.

Deemer, C., Frederics. N. (2006). Dance on Glass Ceiling, Optimist, İstanbul.

Demiray, H. T. (2007). Social Sex and Secretarial, VI. National Bureau Management and Secretarial Congress, Ankara, 343-351.

Güldal, D. (2006). A Research about the Factors that Motivate and Demotivate Women Managers (Published Master's Thesis), Çukurova University Institution of Liberal Arts Department of Business.

Harcar, T., Çakır, Ö., Sürgevil, O. and Budak. G (2008). Violence Against Women and the Situation of Violence Against Women in Turkey. Community and Democracy Magazine, Volume:2, Number:4, p.51-70.

Hopman, H. A. and Lord, B. L. (2009) The Glass Ceiling and Women in Accounting. Interdisciplinary Perspectives on Accounting Conference, Innsbruck, Austria, 9-11 August 2009: 1-41.

Karaca, A. (2007). Career Obstacles for Women Managers: A Research with Application about Glass Ceiling Syndrome. (Published Master's Thesis), The University of Selçuk Institute of Social Sciences Department of Management and Organisation.

Lockwood, N.R. (2004). The Glass Ceiling: Domestic and International Perspectives.

Mescon, M. H., Courtland B. L. and Thill. J. V. (2001). Business Today, Prentice Hall, New Jersey.

Mestçioğlu, Ö. (2016) .Women as Manager. https://www.psikonet.com/yonetici-konumunda-kadin_nedir214.html (04.02.2016)

Onay, M. (2009). Consequences of Sexual Discrimination and an Empirical Research about the Subject. 17. Book of National Management and Organisation Congress, Eskişehir, 21-23 May 2009, p. 285-291.

Ögüt, A. (2006). The Hardships for Women Managers and Initiation in Turkey: Glass Ceiling Syndrome.C.O.M.U. Initiation and Development Magazine, Volume:1, Number:1, p. 56-78.

Palmer, M. and Hyman. B. (1993) Trans. Vedat Üner, Women in Management, Rota Publish, İstanbul.

Ruderman, M. N. and Ohlott. P. J. (2005) Trans. Sinem Özer, Control Your Fate Successful Formula of Working Woman, Optimist Publisher, İstanbul.

Sezen, Bayram. (2008) "Glass Ceiling Obstacle for Women Managers in Business; Research at Middle and High Scaled Hotels", (Published Master's Thesis), The University of Çanakkale Onsekiz Mart 
University Faculty of Social Sciences Department of Tourism Business.

Yelkikalkan, N. (2006). Role of Sex in Successful Initiation, Women Initiates. C.O.M.U. Initiation and Development Magazine, Cilt:1, Sayı:1, ss. 45-55.

Yoğun Erçen, A. E. (2008). Strategies of Women in Overcoming Glass Ceiling- An Insight at Turkish High Scale Businesses, (Published Doctorate's Thesis), The University of Çukurova Institute of Social Sciences.

https://tr.wikipedia.org/wiki/Ayr\%C4\%B1mc\%C4\%B11\%C4\%B1k (04.02.2016) 